\title{
The ability of UHPC prepared with unpurified sea sand and seawater to protect embedded steel against corrosion
}

\author{
Zuqi Wang $^{1,2,3,}{ }^{*}$, Jing Wang ${ }^{1,2,3}$, Yongxiang Zhou ${ }^{1,2,3}$, Putao Song ${ }^{1,2,3}$, Qingfeng Guan ${ }^{1,2,3}$, Zhiren Zhou ${ }^{1,2,3}$ \\ ${ }^{1}$ Institute of Building Materials, China Academy of Building Research, Beijing 100013, China \\ ${ }^{2}$ State Key Laboratory of Building Safety and Built Environment, Beijing 100013, China \\ ${ }^{3}$ National Engineering Research Center of Building Technology, Beijing 100013, China
}

\begin{abstract}
Preparing concrete with unpurified sea sand and seawater is of great significance for the construction in coastal areas short of river sand and pure water. However, unpurified sea sand and seawater contain a lot of chloride ions which may cause steel corrosion problems. In this paper, unpurified sea sand and seawater are used to prepare ultra-high performance concrete (UHPC), and the potential differences between the steel bars with protective layer thickness of $5 \mathrm{~mm}$ and $15 \mathrm{~mm}$ and the $\mathrm{Cu} / \mathrm{CuSO}_{4}$ reference electrode under two types of dry-wet cycle and the chloride ion concentrations at different depths from UHPC specimen surface after 40 dry-wet cycles are tested, the UHPC specimens are broken to observe corrosion of embedded steel bars. The results show that UHPC prepared with unpurified sea sand and seawater has good ability to protect embedded steel reinforcement against corrosion under dry-wet cycle conditions in lab.
\end{abstract}

\section{Introduction}

China has a vast sea area with coastlines of 18,000 kilometres, and abundant sea sand reserves [1,2]. If unpurified sea sand and seawater can be used as construction sand in coastal areas, it can save freshwater resources for desalinating sea sand and reap huge economic and ecological benefits. However, unpurified sea sand and seawater have a high concentration of chloride ions. Chloride ions can accelerate the corrosion of steel bars and reduce the bond between the steel bars and concrete, which will cause great safety risks to construction engineering [3-6]. In coastal areas in China such as Ningbo and Zhoushan in Zhejiang Province, there have been many engineering damage cases caused by unpurified sea sand [7]. Therefore, how to safely and economically use unpurified sea sand has become a problem for construction engineers to think about.

It is generally necessary to purify the sea sand before concrete preparation. Chloride ion in the unpurified sea sand will migrate to the surface of steel bars in concrete, which may cause the damage of the passive film on the surface of steel bars. If there is appropriate amount water and oxygen on the surface of the steel bars after the failure of the passive film, the steel bar will be corroded. However, high density and low porosity are the most significant characteristics of UHPC. It may be difficult for chloride ion to migrate in UHPC and the content of water and oxygen in UHPC may be very low, thus providing technical feasibility for the preparation of UHPC with unpurified sea sand and seawater. Whether
UHPC prepared with unpurified sea sand and seawater has enough ability to protect steel reinforcement against corrosion must be studied before application in practical engineering. Research on the ability of UHPC prepared with unpurified sea sand and seawater to protect steel bars against corrosion has not been reported yet.

The half-cell potential method is commonly used to estimate the risk of corrosion of steel bars in concrete [8]. It is non-destructive, simple and cheap. Herein, we therefore designed an improved half-cell potential method to compare the half-cell potential for different dry-wet cycles, different numbers of cycles, different layer thicknesses and different UHPC proportions. Then we broke the specimens after a certain number of drywet cycles to observe the corrosion of steel bars and measure the water-soluble chloride ion concentrations at different depths from surface of UHPC specimens

\section{Experimental Procedures}

\subsection{Materials and mix proportions}

\subsubsection{Materials}

A typical commercial ordinary Portland cement $(\mathrm{P} \cdot \mathrm{O}$ 42.5, produced by Jidong Cement Plant, China) was used in this study with mechanical properties detailed in Table 1.

* Corresponding author: zuqiwang@126.com 
Table 1. Mechanical properties of $\mathrm{P} \cdot \mathrm{O} 42.5$ cement

\begin{tabular}{|c|c|c|c|}
\hline \multicolumn{2}{|c|}{ Compressive strength/MPa } & \multicolumn{2}{|c|}{ Flexural strength/MPa } \\
\hline $7 \mathrm{~d}$ & $28 \mathrm{~d}$ & $7 \mathrm{~d}$ & $28 \mathrm{~d}$ \\
\hline 34.4 & 50.06 & 7.95 & 8.96 \\
\hline
\end{tabular}

The unpurified sea sand was obtained from Fujian Province, China, which is shown in Fig. 1. Sieve analysis and physical properties were carried out on the sea sand specimens according to Chinese code JGJ 2062010 as shown in Fig. 2 and table 2.

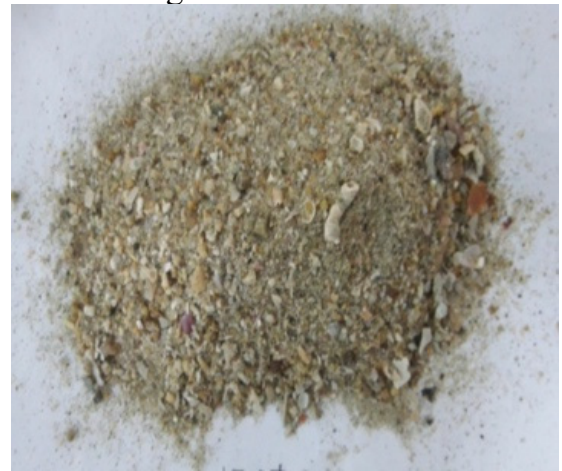

Fig. 1. The unpurified sea sand from Fujian Province, China

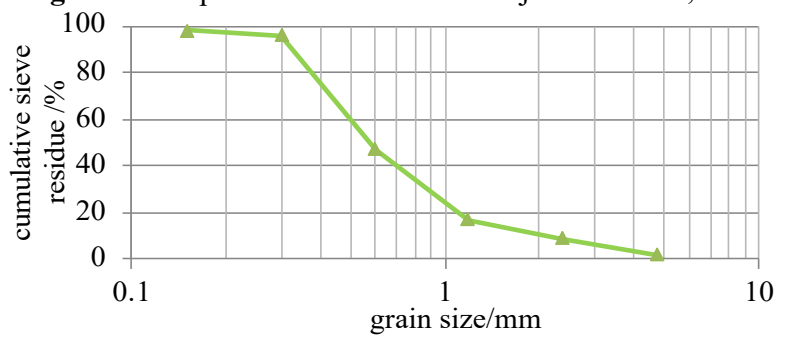

Fig. 2. The grain size distribution curve of the unpurified sea sand
A commercial quartz sand was used to compare with the sea sand, which has the same grain size distribution as that of the sea sand and $\mathrm{SiO}_{2}$ content not less than $99.0 \%$.

Two kinds of water were used. One is fresh water, and the other is $3.5 \%$ (mass fraction) $\mathrm{NaCl}$ solution to simulate sea water.

Other materials involved in the experiments include silica fume( properties as shown in table 3 ), viscosity reducer CABR-J1 produced by CABR Building Materials co., $\operatorname{Ltd}($ properties as shown in table 4), polycarboxylic acid superplasticizer with solid content of $39 \%$ and water reduction rate of $30 \%$ and defoamer with solid content of $30 \%$ which were both produced by Tianjin Yueming Technology Development Co., Ltd, and steel fiber with length of $13 \mathrm{~mm}$, diameter of $0.2 \mathrm{~mm}$ and tensile strength of $2850 \mathrm{MPa}$ produced by Beijing Huicheng Foundation Co., Ltd.

\subsubsection{Mix proportions}

Four mixes were cast and cured in steam at $70{ }^{\circ} \mathrm{C}$ for 48 hours. Mix proportions and compressive strength are as shown in Table 5.

Table 2. Physical properties of the unpurified sea sand

\begin{tabular}{|c|c|c|c|c|c|c|c|c|}
\hline $\begin{array}{c}\text { Apparent density } \\
\left(\mathrm{kg} / \mathrm{m}^{3}\right)\end{array}$ & \multicolumn{2}{|c|}{$\begin{array}{c}\text { Bulk density } \\
\left(\mathrm{kg} / \mathrm{m}^{3}\right)\end{array}$} & $\begin{array}{c}\text { Mud content } \\
(\%)\end{array}$ & $\begin{array}{c}\text { Crush value } \\
(\%)\end{array}$ & $\begin{array}{c}\text { Moisture } \\
\text { content }(\%)\end{array}$ & $\begin{array}{c}\text { Fineness } \\
\text { modulus }\end{array}$ & $\begin{array}{c}\text { Chloride ion } \\
\text { content }(\%)\end{array}$ & $\begin{array}{c}\text { Shell content } \\
(\%)\end{array}$ \\
\cline { 2 - 7 } & Loose & Close & & 3.53 & 0.34 & 1.09 & 0.073 & 10.02 \\
\hline 2520 & 1370 & 1490 & 0.64 & 0.34 & \\
\hline
\end{tabular}

Table 3. Properties of silica fume

\begin{tabular}{|c|c|c|c|c|c|}
\hline $\begin{array}{c}\mathrm{SiO}_{2} \text { content } \\
/ \%\end{array}$ & $\begin{array}{l}\text { Specific surface area } \\
\qquad /\left(\mathrm{cm}^{2} / \mathrm{g}\right)\end{array}$ & $\begin{array}{l}\text { Water demand ratio } \\
\qquad / \%\end{array}$ & $\begin{array}{c}\text { Water content } \\
\qquad / \%\end{array}$ & $\begin{array}{c}\text { Ignition loss } \\
\qquad / \%\end{array}$ & $\begin{array}{l}\text { 28d activity index } \\
\qquad / \%\end{array}$ \\
\hline 94.6 & $2.09 \times 10^{4}$ & 111 & 0.4 & 1.17 & 120 \\
\hline
\end{tabular}

Table 4. Properties of viscosity reducer CABR-J1

\begin{tabular}{|c|c|c|c|c|c|}
\hline \multirow{2}{*}{$\begin{array}{c}\text { Specific surface } \\
\text { area } /\left(\mathrm{m}^{2} / \mathrm{kg}\right)\end{array}$} & Water demand ratio/\% & \multicolumn{2}{|c|}{ Activity index $/ \%$} & \multirow{2}{*}{$\begin{array}{c}\text { Emptying time ratio of inverted slump } \\
\text { cylinder } / \%\end{array}$} & $\begin{array}{c}\text { Chloride ion } \\
\text { content } / \%\end{array}$ \\
\hline 1159 & 88 & $7 \mathrm{~d}$ & $28 \mathrm{~d}$ & 42 & 0.057 \\
\hline
\end{tabular}

Table 5. Mix proportions and compressive strength $\left(\mathrm{kg} / \mathrm{m}^{3}\right)$

\begin{tabular}{|c|c|c|c|c|c|c|c|c|}
\hline $\begin{array}{c}\text { Sample } \\
\text { number }\end{array}$ & $\begin{array}{c}\text { P.O 42.5 } \\
\text { cement }\end{array}$ & $\begin{array}{c}\text { Silica } \\
\text { fume }\end{array}$ & $\begin{array}{c}\text { Viscosity } \\
\text { reducer } \\
\text { CABR-J1 }\end{array}$ & Sand & Water* & Superplasticizer & $\begin{array}{c}\text { Defoamer } \\
\text { fiber }\end{array}$ & $\begin{array}{c}\text { Compressive } \\
\text { strength (MPa) }\end{array}$ \\
\hline SWZ & 756 & 162 & 162 & $\begin{array}{c}1080 \text { (quartz } \\
\text { sand) }\end{array}$ & $\begin{array}{c}173 \text { (Fresh } \\
\text { water) }\end{array}$ & 43.2 & 0.54 \\
\hline HYZ & 756 & 162 & 162 & $\begin{array}{c}1080(\mathrm{sea} \\
\text { sand) }\end{array}$ & $\begin{array}{c}173 \text { (NaCl } \\
\text { solution) }\end{array}$ & 43.2 & 0.54 & 0 \\
\hline HYSZ & 744 & 159 & 159 & $\begin{array}{c}1063(\mathrm{sea} \\
\text { sand) }\end{array}$ & $\begin{array}{c}170 \text { (NaCl } \\
\text { solution) }\end{array}$ & 42.5 & 0.53 \\
\hline
\end{tabular}

\footnotetext{
* Containing water in superplasticizer and defoamer.
} 


\subsection{Experiments}

\subsubsection{Specimen preparations}

A typical hot-rolled plain steel bar (HPB300) with length of $100 \mathrm{~mm}$ were prepared and cleaned in accordance with CECS 13-2009 Fiber Concrete Test Method Standard. A mold of $100 \mathrm{~mm} \times 100 \mathrm{~mm} \times 100 \mathrm{~mm}$ were used. Two thin plastic plates with two circular holes as shown in Fig. 2 were placed inside the mold close to both ends. Two steel bars were inserted into the circular holes of the plates to ensure that the steel bars are parallel with protective layer thickness of $5 \mathrm{~mm}$ and $15 \mathrm{~mm}$. High performance concrete was mixed with a twin-shaft mixer, poured into the mold. After concrete was hardened, one exposed ends of the steel bars were connected to the wires and the other ends were sealed with epoxy. The specimens were cured in steam at $70{ }^{\circ} \mathrm{C}$ for 48 hours and dried at $80 \pm 5^{\circ} \mathrm{C}$ for $24 \mathrm{~h}$.

Simultaneously, specimens without steel bars with the same mix proportions were formed. Some were placed in the standard curing room, and the others were dry-wet cycled synchronously with the steel-containing specimens.
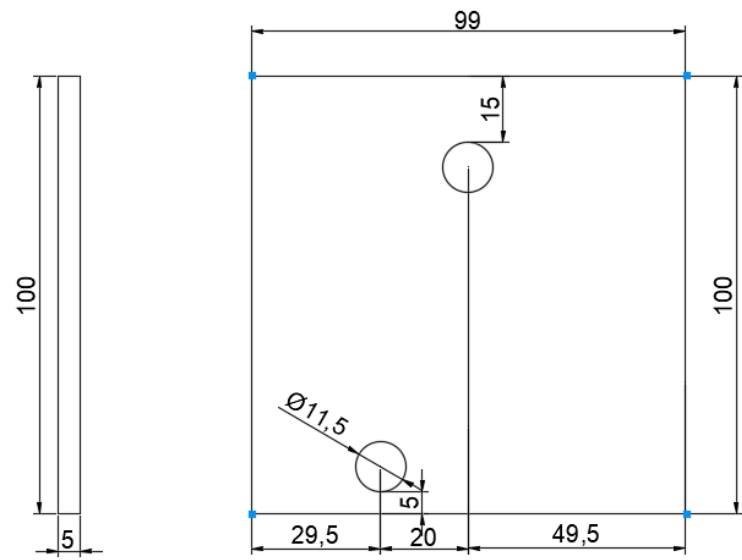

Fig. 3. Dimensions of thin plastic plates $(\mathrm{mm})$

\subsubsection{Experiments}

Two types of dry-wet cycles ( recorded as "S4D3" and "S2D1") were applied to the specimens. Each dry-wet cycle of "S4D3" was defined as 4-day soaking in 3.5\% (mass fraction) $\mathrm{NaCl}$ solution and 3-day drying in $60^{\circ} \mathrm{C} \pm 5^{\circ} \mathrm{C}$ oven. Each dry-wet cycle of "S2D1" was defined as 2-day soaking in 3.5\% (mass fraction) $\mathrm{NaCl}$ solution and 1-day drying in $60^{\circ} \mathrm{C} \pm 5^{\circ} \mathrm{C}$ oven. Potential differences between the steel bars and $\mathrm{Cu} / \mathrm{CuSO} 4$ reference electrod (CSE) were mearused using a multimeter every 4 cycles (for S4D3) or every 5 cycles (for S2D1). After 40 cycles for S2D1, specimens were broken, and corrosion area of each steel bar were test. The concentrations of water-soluble chloride ion at different depths in the specimens without steel bars were tested according to JGJ/T 322 Technical specification for test of chloride ion content in concrete.

\section{Results and discussion}

\subsection{Potential differences between the steel bars and CSE}

\subsubsection{S4D3 cycle (4-day soaking and 3-day drying for each cycle)}

Potential differences between the steel bars and CSE for different number of cycles are shown in Fig. 4 Fig. 6.

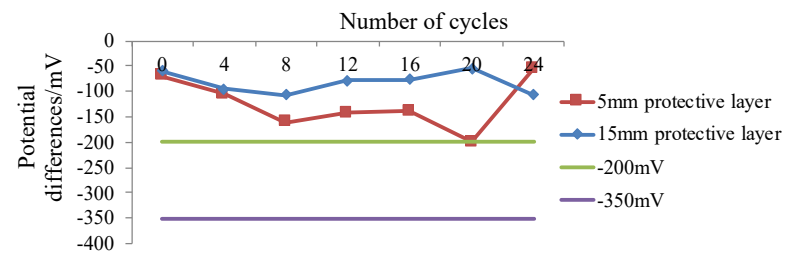

Fig. 4. Potential differences of steel bars with different protective layer thicknesses and CSE of SWZ (for S4D3 cycle)

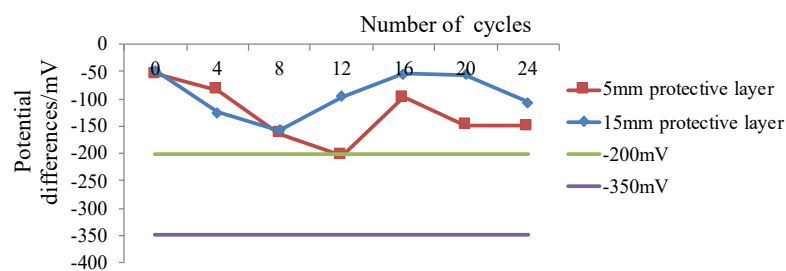

Fig. 5. Potential differences of steel bars with different protective layer thicknesses and CSE of HYZ (for S4D3 cycle)

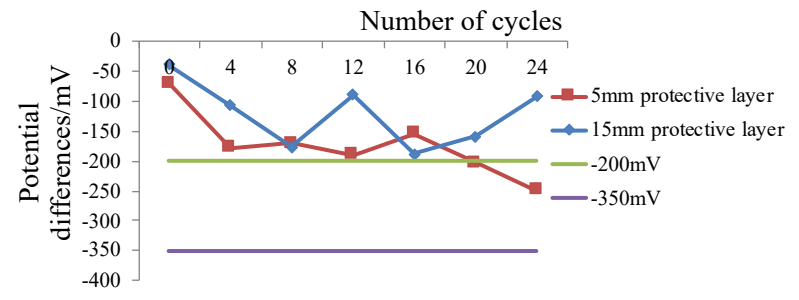

Fig. 6. Potential differences of steel bars with different protective layer thicknesses and CSE of HYSZ (for S4D3 cycle)

As the Fig.s above show, there is no obvious difference in the change trend of the potential differences of different proportions of UHPC, potential differences fluctuate with the number of cycles, mostly potentials of steel bars with $5 \mathrm{~mm}$ protective layer are positive than that of steel bars with $15 \mathrm{~mm}$ protective layer, most of potentials are positive than $-200 \mathrm{mV}$ CSE and all the potentials are positive than $-350 \mathrm{mV}$ CSE. According to ASTMC876-2015[9], if potentials are more positive than-200mV CSE, there is a greater than $90 \%$ probability that no reinforcing steel corrosion is occurring, if potentials are in the range of $-200 \mathrm{mV}$ to $-350 \mathrm{mV}$ CSE, corrosion activity of the reinforcing steel in that area is uncertain, if potentials are more negative than $-350 \mathrm{mV}$ CSE, there is a greater than $90 \%$ probability that reinforcing steel corrosion is occurring. Therefore, there is a greater than $90 \%$ probability that no steel bar corrosion is occurring in SWZ, HYZ and HYSZ for 40 cycles. 


\subsubsection{S2D1 cycle (2-day soaking and 1-day drying for each cycle)}

Potential differences between the steel bars and CSE for different number of cycles are shown in Fig. 7 Fig. 10.

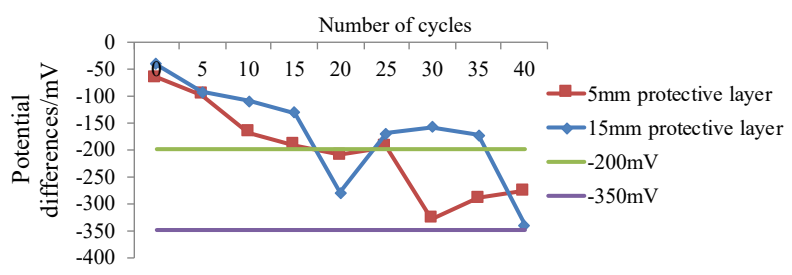

Fig. 7. Potential differences of steel bars with different protective layer thicknesses and CSE of SWZ (for S2D1 cycle)

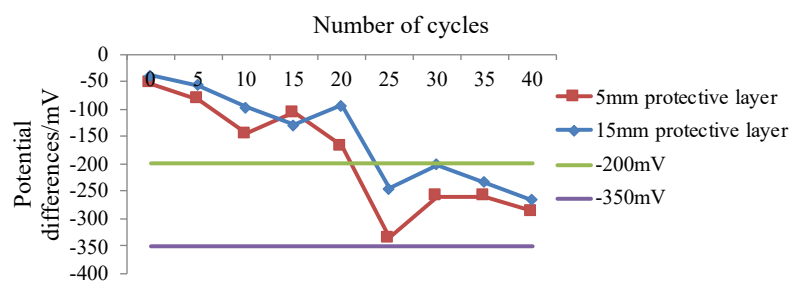

Fig. 8. Potential differences of steel bars with different protective layer thicknesses and CSE of HYZ (for S2D1 cycle)

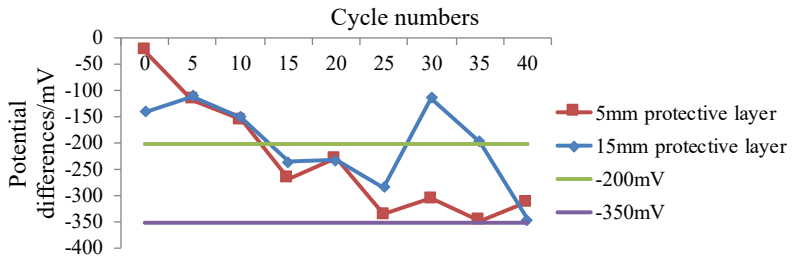

Fig. 9. Potential differences of steel bars with different protective layer thicknesses and CSE of HYSZ (for S2D1 cycle)

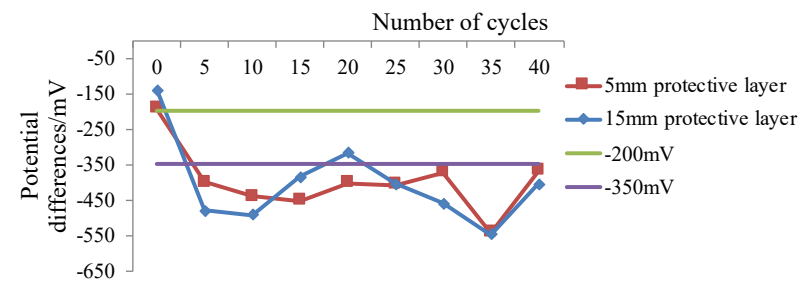

Fig. 10. Potential differences of steel bars with different protective layer thicknesses and CSE of artificially fractured HYSZ (for S2D1 cycle)

It can be seen from Fig. 7 that after 5 S2D1 cycles, the potential differences between steel bar with $5 \mathrm{~mm}$ and $15 \mathrm{~mm}$ protective layer and CSE in artificially fractured HYSZ are all negative than $-350 \mathrm{mV}$, which means that there is a greater than $90 \%$ probability that steel bars are corroding. It's because the artificial cracks caused chloride ions to quickly enter the specimen and reach the surface of the steel bars, causing corrosion of the steel bars. Compared to S4D3 cycle, the potential differences between steel bars and CSE for S2D1 cycle have a larger fluctuation range. Potential differences in SWZ, HYZ and HYSZ generally show a downward trend with the number of cycles. In addition, the number of cycles corresponding to the first time when the potential difference in SWZ, HYZ and HYSZ is negative than $200 \mathrm{mV}$ is 20,25 and 15 respectively. After then, the potential differences are always positive than $-350 \mathrm{mV}$. Therefore, at the beginning of the S2D1 cycle, the probability of steel corrosion is very low. As the cycle continues, the probability of steel corrosion becomes uncertain.

After 40 cycles, all the specimens were broken. The steel bars in artificially fractured HYSZ were severely corroded and the corrosion areas of the two steel bars both exceeded $90 \%$, as shown in Fig. 8 and 9. And in SWZ, HYZ and HYSZ, no steel corrosion occurred. The steel bars in HYSZ were shown in Fig. 11 and 14.

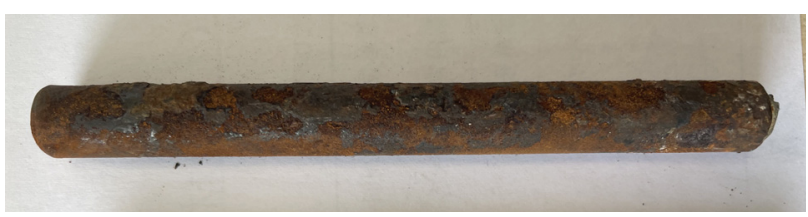

Fig. 11. The steel bar with $5 \mathrm{~mm}$ protective layer in artificially fractured HYSZ after 40 S2D1 cycles

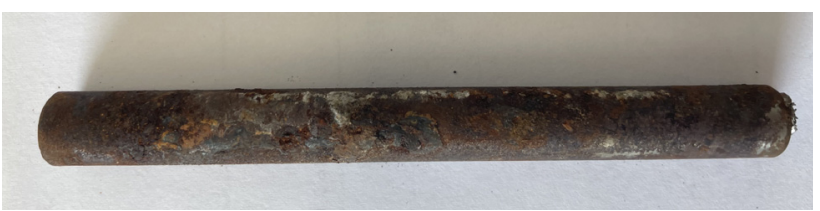

Fig. 12. The steel bar with $15 \mathrm{~mm}$ protective layer in artificially fractured HYSZ after 40 S2D1 cycles

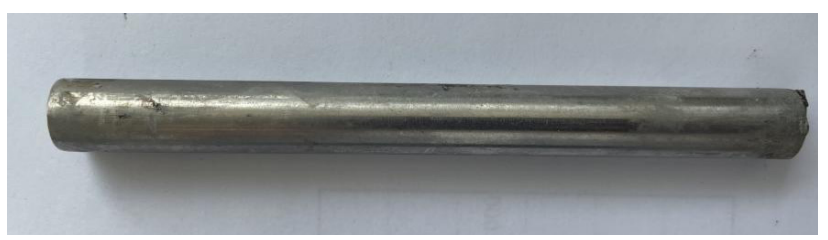

Fig. 13. The steel bar with $5 \mathrm{~mm}$ protective layer in HYSZ after 40 S2D1 cycles

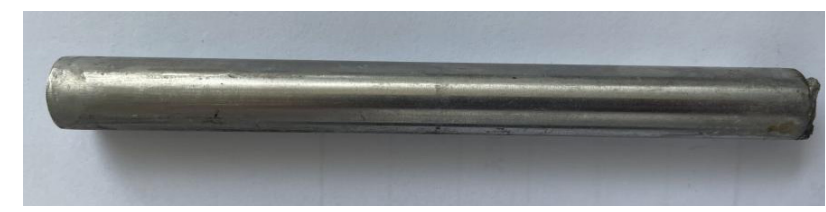

Fig. 14. The steel bar with $15 \mathrm{~mm}$ protective layer in HYSZ after 40 S2D1 cycles

\subsection{Water-soluble chloride ion concentration at different depths}

The water-soluble chloride ion concentrations at different depths in UHPC are shown in Fig. 15.

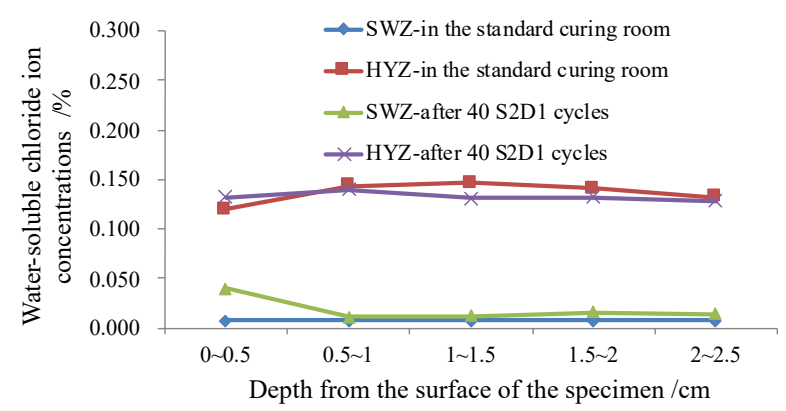

Fig. 15. The water-soluble chloride ion concentrations at different depths 
It can be seen from Fig. 15 that the water-soluble chloride ion concentrations in the HYZ specimens are significantly higher than that in the SWZ specimens. Because $\mathrm{HYZ}$ specimens are prepared with $\mathrm{NaCl}$ solution, and some of the chloride ions from $\mathrm{NaCl}$ solution are not converted into bound chloride ions, but still exist as water-soluble chloride ions.

In addition, after 40 cycles of S2D1, the watersoluble chloride ion concentrations at different depths of the HYZ specimens are basically the same and in the range of $0.12 \%$ to $0.14 \%$. After 40 cycles of S2D1, the water-soluble chloride ion concentration on the surface of the SWZ specimen is higher, and the water-soluble chloride ion concentrations at the other depths of the SWZ specimen are basically the same, and equivalent to the chloride ion concentrations in the SWZ specimen in the standard curing room, approximately around $0.01 \%$. Because the UHPC specimens after steam curing are dense, even after dry-wet cycles, chloride ions can not penetrate into the specimens.

\section{Conclusions}

(1) Unpurified sea sand can be used to prepare ultra-high performance concrete (UHPC). The compressive strength of the UHPC which has a proportion of cement, viscosity reducer, silica fume, unpurified sea sand and seawater is 0.7:0.15:0.15:1.0:0.16 by weight, appropriate amount of superplasticizer and defoamer and 1.5\% volume of steel fiber can reach $141.8 \mathrm{MPa}$ after being cured by $70^{\circ} \mathrm{C}$ steam for $48 \mathrm{~h}$.

(2) The steam-cured UHPC prepared with artificial seawater and sea sand is dense enough to prevent external chloride ions from penetrating into the concrete, and there is no enough water and oxygen on the steel surface even if there are a certain amount of chloride ions from seawater and unpurified sea,the steel will not corrode. So UHPC prepared with seawater and unpurified sea sand has a good ability to protect steel reinforcement against corrosion under dry-wet cycle conditions in lab.

\section{References}

1. X. Gu and M. Tian, China Water Transport 11, 245 (2011).

2. X. Cao, Z. Ling, and J. Guo, Journal of Mianyang Normal University 27, 121 (2008).

3. Y. Shi, D. Wang, and $\mathrm{Z}$. Wu, Engineering Mechanics 27, 212 (2010).

4. W. P. S. Dias, G. A. P. S. N. Seneviratne, and S. M. A. Nanayakkara, Construction and Building Materials 22, 1377 (2008).

5. L. Bian, S. Song, and F. Li, China Concrete and Cement Products 11 (2012).

6. C. Fang, K. Lundgren, L. Chen, and C. Zhu, Cement and Concrete Research 34, 2159 (2004).

7. H. Li, The Study on Emergency Management of "Sea Sand House," Dissertation, Huaqiao University, 2012.

8. V. Leelalerkiet, J.-W. Kyung, M. Ohtsu, and M. Yokota, Construction and Building Materials 18, 155 (2004).

9. G01 Committee, Test Method for Corrosion Potentials of Uncoated Reinforcing Steel in Concrete, ASTM International. 